\title{
The Role of Character Education for Early Children in Early Childhood Education Programs in Happy Kids Bogor Indonesia
}

\author{
Ronny Gunawan \\ Guidance and Counseling Teacher Faculty and Education Training \\ Christian University of Indonesia \\ Jakarta, Indonesia \\ ronigunawan08@gmail.com
}

\begin{abstract}
Character Education is a topic that is being discussed in the world of education in Indonesia. Character education needs to be applied from an early age, as early childhood (between from 2 to 7 years) is a time when people begin to learn about the ways of life and socializing. Where the curriculum of Early Childhood Education is structured not only to teach children about reading, writing, and counting, but teaching children on the ways and values of behavior in society such as courtesy, honesty, discipline, and so forth. Research data obtained from survey results at Early Childhood School in Happy Kids Indonesia, Bogor. Of the 35 respondents, $75 \%$ of parents understood the importance of early childhood education; $85 \%$ of parents understand that there is a strong link between early childhood education and character building for students; Education pattern applied in school with approach to play, study, spiritual, and culture.
\end{abstract}

Keywords-Education, Character, Early Childhood, and Behavior

\section{INTRODUCTION}

Character is a part of human life that can not be seen by the naked eye because it is far behind human life, but character can be manifested by human person through behavior and everyday behavior. Characters in the language of psychology are more familiar with the word personality. Human personality is formed not only from attributes that are passed on by the parents, but also can be shaped by the environment, such as the family environment, the school, and the community in which the person lives. Apart from the human character environment can also develop based on the human age, usually the more mature age, then the person will be more mature. Speaking of the learner means talking a human life that never gets away from the name of the character. Character is a combination of all human persons derived from genes (innate), environment (family and social), and time. In character there is a temperament that can not be changed, but humans can minimize the downside. In the sense of the character that the character in the base also by GEN. In order to better understand personality development, it is important to examine potential sources of changes in personality traits. Behavior genetic studies have to be addressed to the question of the genetic influences, environmental experiences, or both contribute to stability and change in temperament and personality traits in childhood, adolescence, and adulthood [1].

Many cases occur in human life, such as juvenile delinquency, the use of narcotics, abortion, and so on which is actually a reflection of the human personality. In life, humans have two sides of the personality that can not be separated like a currency (there is a reciprocity), which is on the side of a positive personality and on the other side of a negative personality. Every human being has two sides. Therefore how to build that personality, that is what is important in human life, not talking about erasing negative personality. Building human personality has never been separated from the role of education, especially early education, ie early childhood education. Early childhood schools have an important role in building the human personality to evoke a positive personality that exists within the human being.

Given the development and condition of the young generation in Indonesia, where young people are heavily affected by drugs and abortion (data source: CNN Indonesia, April 2015) and divorce in families in Indonesia (data source: BKKBN, 2014) Applied in a balanced, adaptive, and up to date. Equal character education is character education tailored to the current psychological-social situation of character education that emphasizes the generation of a drug nation, free sex, abortion and divorce. In the course of human development requires education in accordance with the age of its development, therefore the character education needs to be 
balanced with the age of learners. Age-appropriate character education The learner will have a significant effect on the psychological-social development of the learner.

Early Childhood Education is the foundation of the formation of human personality, such as teaching how to behave decently in everyday life. The formation of the child's personality from an early age greatly influences his character in his social life in society. From the results of research that has been done by Alicia Benavides-Nieto said that the highest socialization life in human life starts from early childhood [2]. In light of the contention that early temperament plays a foundational role in future personality development [1]; Rothbart \& Bates, 2006; [3], there has been increased interest in the Differential stability (or consistency) of temperament [3].

When children interact with groups, they explore their personal values, beliefs, attitudes, decisions and receive feedback from their peers. In the process of expressing these feelings, children learn social skills effectively and gain empathy, greater attention to the needs and feelings of others [4]. On the other hand there is a developmental theory related to moral planting and character saying that: the relationship of educators-learners need to be warm, supportive, and trusting, the classroom needs to be a caring and democratic community, where the needs of each learner will be competence, Autonomy, and sense of belonging are met, learners will need the opportunity to discuss and improve their understanding of moral values and how to apply them to everyday life in the classroom [5].

Early childhood education can start from the age of 2 to 6 years with class divisions as follows: palygroup grade 2 - 4 years old, where the child is trained to socialize with the environment outside of himself and his family, ie his friends through playing and singing; A kindergarten class A, ages 4 - 5 years in which children are introduced to letters and numbers but still in the context of play; And kindergarten class B, age 5 - 7 years, in which the child has started his cognitive training in the context of the game to be able to compose a sentence, and counting.

The seven major virtues that every educator can follow. The seven virtues are indispensable for the child to do the right thing; Also to face ethical opposed pressures, namely: Empathy (understanding and feeling the concerns of others); Conscience (knowing and applying the right way of acting); Self-control (controlling thoughts and actions in order to withstand the urge from within and outside, so that it can act correctly); Respect (respect for the welfare and feelings of others) Tolerance (respecting the dignity and rights of all people even if their beliefs and behaviors are different from ours) Justice (open thinking and fair action And true) [4] Based on the discussion, the researcher focuses this research on Child Character
Development Since Early Age at School of Early Childhood Education Happy Kids Indonesia, Cilebut, Bogor Regency.

The formation of a child's character needs to be realized by every parent and teacher, therefore parents and teachers should have a focus on shaping the character of the child. Child characters can be formed through each senses they have, especially the eyes and hearing. Children often imitate what they see and hear from their surroundings, such as their parents and relatives and friends. What they see and hear they imitate through their daily behavior.

In addition, personality development during childhood and adolescence contains key differences from personality development during adulthood, thus requiring unique scientific attention [6].

\section{METHOD}

\section{II.1. Participation}

The Object of this Research is Early Childhood Education Kids Early Education Happy Kids Indonesia, Cilebut-Bogor, West Java. Sources of data taken by researcher as many as 15 people, where in the school there are 5 teachers, and 35 parents of students who become the source of data.

\section{II.2. Procedure}

The research method used in this study is a method of descripting data obtained and synchronized with existing theories. The data retrieval technique through interview with the instrument of interview and survey guide. Data collection is done during the parent meeting in a seminar

\section{II.3. Measurement}

Measurements used in this study are data analysis of interviews and survey results developed in 3 (three) dimensions, namely: parental understanding of the childhood education, and the linkage of early childhood education with the character Of students.

\section{RESULT}

The results of this study are described according to the three dimensions measured in the study, namely: understanding of parents to early childhood education, the pattern of education applied in schools, and early childhood education with the character of students. Here are the results of these three dimensions: 


\section{III.1. Understanding Parents of Early Childhood Education}

In this study present 35 respondents as sample research. Of the ten respondents, it was found that $25 \%$ of parents sending children to Early Childhood Education have not understood the importance of sending their children to school in early childhood education; $75 \%$ of parents understand the importance of early childhood education.

\section{III.2. Pattern of Education applied in School}

From the results of interviews with the five teachers in the school can be obtained that the pattern of education applied is the pattern of education with the approach of play, learning, spiritual, and culture.

\section{III.3. Correlation of Early Childhood Education with Student Character}

Of the 40 respondents with the division of 5 teachers and 35 parents, $85 \%$ found that there is a close correlation between early childhood education and character building in students, while $15 \%$ do not know the corelated between early childhood education and student character.

\section{IV.DISCUSSION}

The formation of a child's character is the basis of the formation of the human personality of mankind and nation. Through the character of society, a nation may become advanced or collapsed. A person's character may affect the environment in which the person lives. Educational beliefs that are supposed to enhance the specific competences and traits of children (Wilfried Smidt, Gisela Kammermeyer, Susanna Roux, 2015). Based on the research results obtained, the researcher describes the results in three major sections in accordance with the existing dimensions, namely:

\section{IV.1. Understanding Parents of Early Childhood Education}

Human beings is a who can not be separated from education. The human structure and situations in the world make the learning process inevitable. Learning and teaching are the woven threads of human existence which can not be removed and destroyed, for man is surrounded and surrounded by change; Every day brings something new under the sun that shines on human life [7].

From the results of the study there is a considerable trend, namely $75 \%$ of parents understand for what sending their children from an early age. Parents began to be built thinking that children who have begun schooled at an early age will have a different development compared with children who go straight to elementary school. The difference lies in, when children enter into early childhood education, children are trained to develop affective and psychomotor sides more than cognitive, in addition to children being trained to have socialization and ethics to get along, but in elementary schools, the existing education is cognitive-centered only.

Some parents who do not understand the importance of early childhood education often neglect their children, so they do not send it to school early education. Parents prefer to take their children to study in the guidance of learning while waiting for the child's age enough to enter elementary school. Some of the children who do not have early education will have difficulty socializing and personality development, because the place where the guidance of learning is only the formation of the cognitive domain.

\section{VI.2 Pattern of Education applied in School}

The pattern of Spiritual Education is an educational pattern that emphasizes religion, to the extent that human beings can understand their religion which has an impact on the development of their character starting from early childhood education. After the children have paid attention to God, since then, little by little he has an empirical experience about religion [8]. A number of life skills that need to be taught to students include: responsible way of living; Develop selfesteem; Doing the right thing; Respect others; Face conflict; Avoiding violence; Develop the value of life; Say no to drugs and alcohol; Attitudes toward sex; Life aims; Face pressure; Managing emotions; Building and building friendships; And ways of living with parents and family [9].

Thus every early child who enters in early childhood education receives learning that develops affective and psychomotor abilities, so that when the child enters the primary school they are ready to live life on the next level. Another of the processes of working with the cognitive flexibility, facilitates the resolution of social conflicts (e.g. Ziermans et al., [10]. In Early Childhood Education is more emphasized on the aspect of character development through an affective and spiritual centered curriculum.

Often schools of early childhood in Indonesia, especially in Bogor more emphasized aspects of literary reading than the formation of personality through learning centered on affective and psychomotor domains. The reasons for early schooling emphasize the cognitive domain is when the children enter the elementary school they can pass the entrance test and received at the school. Principles like this often happen in Indonesia, because early childhood schools are more pursuing the target so that children can be accepted in the favorite elementary school. 
VI.3. Correlation of Early Childhood Education with Student Character

In Early Childhood Education developed child emotions that affect the psyche compared with the cognitive side, because emotion is one side of the human personality. Emotion is one dimension in human mental operation. It appears in the form of signals and individual responses to make changes in action in relation to the physical and social environment [11]. Therefore in the Early Childhood Education curriculum is not oriented to the cognitive aspect but has an orientation that focuses on the development of affective, psychomotor, and spiritual aspects. Through this research results obtained most parents with teachers realize that early childhood education has a relationship with the development of children's character. Therefore, it is important to build the character of children from an early age through early childhood education.

This study is a reference for Early Childhood Education and parents who have early childhood. Early childhood schools should have character education for their students, since the character building of children from an early age will have a positive effect on the child's future to the nation's future. The early childhood school curriculum not only implements cognitive learning, but also considers affective and psychomotor domains as the foundation of character education.

\section{ACKNWOLEDGMENT}

Early childhood education is an important element in building human character. Character development is closely related to education, especially early childhood education, because from the age of age the character needs to be planted. Therefore building character needs to be started from early childhood. Become a focus for teachers and parents to bring in children ages 2 - 6 and educate them in early childhood education.

Thank you to the Christian University of Indonesia which supports me in writing this article both in fund and guidance.

\section{REFERENCE}

[1] Shiner Rebecca L, Timothy A. Allen, Ann S. Masten (2016). The Prediction of Changes in Personality Traits from Childhood to Adulthood from Adversity in Adolescence. Journal of Research in Personality, 54

[2] Nieto Alicia Benavides, Miriam Romero-López, Ana Belén QuesadaConde \& Guadalupe Alba Corredor. 2017. Basic Executive Functions in Early Childhood Education and their Relationship with Social Competence. Procedia - Social and Behavioral Sciences 237, 478

[3] Neppl Tricia K., M. Brent Donnellan, Laura V. Scaramella, Keith F. Widaman, Sarah K. Spilman, Lenna L. Ontai, Rand D. Conger (2010).
Differential stability of temperament and personality from toddlerhood to middle childhood Journal of Research in Personality 44, 396

[4] Djiwandono Sri Esti Wuryani. (2005). Konseling dan Terapi dengan Anak dan Orangtua. Jakarta: PT. Grasindo, 261.

[5] Larry P. Nucci \& Darcia Narvaez. (2014). Handbook Pendidikan Moral dan Karakter. Bandung: Nusa Media, 262.

[6] Ziyan Luan, Roos Hutteman, Jaap J.A. Denissen, Jens B. Asendorpf, Marcel A.G. van Aken (2016). Do You See My Growth? Two Longitudinal Studies on Personality Development from Childhood to Young Adulthood from Multiple Perspectives, 3

[7] Wolterstorff. Nicholas P. (2007). Mendidik Untuk Kehidupan. Surabaya: Momentum, 4

[8] Sidjabat, B.S. (2011). Membangun Pribadi Unggul. Yogyakarta: Andi Offset, 265.

[9] Lopez Miriam Romero, Ana Belén Quesada-Condea, Gloria Álvarez Bernardob \& Ana Justicia-Arráez (2017). The Relationship between Executive Functions and Externalizing Behavior Problems in Early Childhood Education. Procedia - Social and Behavioral Sciences 237, 783

[10] Saptono. (2011). Dimensi-Dimensi Pendidikan Karakter. Erlangga, 152.

[11] Michele Borba. Membangun Kecerdasan Moral. Jakarta: PT. Gramedia Pustaka Utama, 9.

[12] Smidt Wilfried, Gisela Kammermeyer, Susanna Roux (2015). Relations between the Big Five personality traits of prospective early childhood pedagogues and their beliefs about the education of preschool children: Evidence from a German study 37, 97

[13] Sidjabat, B.S. (2011). Membangun Pribadi Unggul. Yogyakarta: Andi Offset, 265. 